\title{
The Formation of the Sahara Desert: Evidence for the Slow Ending of the Great Ice Age
}

\author{
Kari Hänninen \\ Department of Biological and Environmental Sciences, University of Jyväskylä, Finland
}

Received February 25, 2021; Revised April 14, 2021; Accepted April 26, 2021

\section{Cite This Paper in the following Citation Styles}

(a): [1] Kari Hänninen, "The Formation of the Sahara Desert: Evidence for the Slow Ending of the Great Ice Age," Environment and Ecology Research, Vol. 9, No.2, pp. 76 - 91, 2021. DOI: 10.13189/eer.2021.090204.

(b): Kari Hänninen (2021). The Formation of the Sahara Desert: Evidence for the Slow Ending of the Great Ice Age. Environment and Ecology Research, 9(2), 76 - 91. DOI: 10.13189/eer.2021.090204.

Copyright $\bigcirc 2021$ by authors, all rights reserved. Authors agree that this article remains permanently open access under the terms of the Creative Commons Attribution License 4.0 International License

\begin{abstract}
The aim of this meta-study is to provide an understanding of the events which slowly ended the Great Ice Age (GIA) and caused the formation of the Sahara Desert. During the GIA, a layer of floating ice $900 \mathrm{~m}$ thick in the Arctic Ocean and grounded ice in the North Sea prevented the flow of the Gulf Stream into the Arctic Ocean. An 8-km layer of salt at the bottom of the Gulf of Mexico suggests that the gulf has been an inland sea for a long period. It might have been separated from the Atlantic Ocean by an overflow via the Straits of Florida and a land bridge in the Yucatan Channel, which was reflected the North Equatorial Current (NEC) flow towards the coast of Northwest Africa as the GIA-Gulf Stream (GIA-GS). During the GIA, the return waters by the GIA-GS were warm, and the Sahara was "green." About 11,300 to 11,600 years ago, an earthquake might have cut the land bridge connecting the gulf to the Atlantic Ocean. This allowed the Gulf Stream Currents (GSC) to occupy their present flow route. Within 4,000 to 5,000 years, grounded and floating ice and continental glaciers had melted and the global sea level risen by 10 to 15 meters. By then, the return flow of water carried by the GSC into the Arctic Ocean was fully developed: first via undercurrents (mainly) into the Labrador Sea, and then from there to the coast of Northwest Africa as the North Atlantic Undercurrent (NAUC). Its upwelling waters desiccated the sea-air entering the Sahara. Paleobiological, paleohydrological, and paleontological observations confirm that the drying of the Sahara started in earnest about 6,000 years ago.
\end{abstract}

Keywords Route Change of the Gulf Stream, Slow Ending of the Great Ice Age, Development of the North Atlantic Undercurrent, Desiccation of Sea Air by Cold
Water and by Cloud Seeding, Formation of the Sahara Desert, Desertification of Sahel Belt

\section{Introduction}

The desiccation of the nearby continental climate by the upwelling waters of cold undercurrents is a typical oceanic-atmospheric phenomenon. This prevents rain-laden sea-air from entering the land. This phenomenon is most conspicuous in the subtropical latitudes (around the Tropic of Cancer and Tropic of Capricorn).

The cold Peru-Humboldt Current (PHC) flows north parallel to the west coast of South America. It creates the $105,000-\mathrm{km}^{2}$ Atacama Desert in northern Chile and southern Peru [1]. The desiccation is effective, the mean annual rainfall is not more than $15 \mathrm{~mm}$ [2]. The Atacama Desert has been arid for at least $22 \mathrm{Ma}$ [3-4]. The Northern Hemisphere counterpart of the PHC in the Pacific Ocean is the California Current, which brings aridity to Baja California.

That cold-water undercurrent from the Antarctic Circumpolar Current (ACC) in the Southern Ocean, which is directed towards Africa, is divided by the African tip into two branches: the Benguela Current (BenC) parallel the western coast and the BenC $\mathrm{E}_{\mathrm{E}}$ parallel the eastern coast of Africa [7]. The BenC leads to the existence of the 34,000 $\mathrm{km}^{2}$ Namib Desert $[1,5]$. Aridity in southwest Africa is at least 5 million years old, predating the onset of the BenC, and it may have been initiated shortly after the opening of the Atlantic Ocean [6] and the development of the South 
Atlantic Ocean currents. The $\mathrm{BenC}_{\mathrm{E}}$ is also known as Agulhas Undercurrent [8]. It creates the harsh, drought-prone environment in southwestern Madagascar. The Somali Current (SomC), which dries the Horn of Africa, is a continuation of the $\mathrm{BenC}_{\mathrm{E}}$.

The Sahara Desert is the largest warm-climate desert, with an area of approximately $9,100,000 \mathrm{~km}^{2}$. Due to the bottom topography, most of the water which the Gulf Stream Currents (GSC) carries into the Arctic Ocean flows first in undercurrents mainly into the Labrador Sea. From there, the North Atlantic Undercurrent (NAUC) carries the water towards the coast of Northwest Africa [7]. The upwelling takes place over $3,500 \mathrm{~km}$ of coastal area from Dakar (NW Africa) to A Coruña (NW Spain) $\left(10^{\circ} \mathrm{N}\right.$ to $43^{\circ} \mathrm{N}$ ) [9]. NAUC waters flow almost perpendicular towards the Northwest African coast, and effectively cool both the coastal sea area and the local atmosphere.

The Sahara Desert is the youngest of all the deserts on Earth. During the past 6,000 years, major changes in biome distributions have occurred in Africa north of $15^{\circ} \mathrm{N}$. Many low-elevation sites were previously steppe and the Saharan mountains featured temperate xerophytic woods/scrub and warm mixed forest. At present those areas are desert. These shifts in biome distributions imply a significant decrease in precipitation between 6,000 years and the present [10].

Recent geomorphological data reveal the existence of a large buried paleo-drainage network of the Tamanrasset River on the Mauritanian coast. Already during the late Quaternary, this river has contributed to the delivery of sediments to the Tropical North Atlantic margin [11]. This means that the West Saharan area needed to receive significant precipitation during the Great Ice Age (GIA).

The Sertão [12] in northeastern Brazil is distinctive for its low rainfall compared to other areas of Brazil. It is a xerophytic shrubland and thorn forest consisting primarily of small, thorny trees that shed their leaves seasonally [1314]. This drying is mainly caused by the upwelling of the Malvinas Current (MalC) water in the Capo Frio region and along the Atlantic coast up to the Baía de Todos os Santos [7]. Stone Age people lived in Sertão between circa 22,000 to $6,000 \mathrm{cal}$ BP [15]. This suggests that the drying of Sertão started around the same time as that of the Sahara.

It has been suggested that during the GIA the Arctic Ocean was covered by a layer of floating ice that was 900 $m$ thick [16]. This means that the shallow Arctic seas (Barents, Kara, Laptev and East-Siberian Seas) as well as the Greenland, Iceland and Svalbard continental shelves were covered by grounded ice. The entire North Sea was also covered by grounded ice [17]. This implies that the Gulf Stream flow at that time was not directed into the Arctic Ocean. This would have required a watertight obstacle - a land bridge - in the Yucatan Channel.

The waters of the North Equatorial Current (NEC) and the contribution of the South Atlantic water brought over the Equator by the North Brazilian Current (NBC) would have reflected from this land bridge back towards the coast of Northwest Africa as a warm current. Sea air entering the Sahara would not have desiccated, and the Saharan area would have received more precipitation than it does today.

The enlargement of the Sahara is a continuing process, the advance of which is a clearly measurable phenomenon. In the mid-19th century, Timbuktu was savannah area [18]. In those days, the preferable route of reaching Timbuktu and the Niger River was north through the world's largest desert rather than from the west coast (Dakar) through dense and unexplored forests [19].

Airborne dust enhances the formation of the precipitation embryos in the atmosphere [20]. It is likely that when the sand deserts in Sahara enlarged, cloud seeding started to play an auxiliary role in the desertification. Today desertification is threatening the Sahel belt, which is a transition zone between desert and tropical savannah [21].

When the GIA ended, the sea level is assumed to have risen by $120 \mathrm{~m}$. This theory is accounted for by the age determinations of coral Acropora palmata at the sea bottom in Barbados. The results were interpreted to show two brief periods of accelerated melting superimposed on a smooth and continuous rise of sea level with no reversals. These so-called meltwater pulse (MWP-1A and MWP-1B) events would have taken place approximately 14,000 and 11,300 years ago respectively. A third, much smaller MWP-3 would have taken place around 7,600 years ago [22].

The first measurements in Tahiti showed that the MWP-1A had taken place 13,800 years ago [23]. This was thought to corroborate the claimed global sea level rise. Later the Tahiti sea level record was updated with offshore drill cores demonstrating that the age of MWP-1A is older by about 500 years than was previously thought based on the Barbados record [24].

Measurements in Tahiti were done starting from the depth of $87 \mathrm{~m}$ upwards [23]. If the sea level 14,000 years ago really would have been $120 \mathrm{~m}$ lower than it is today, the Tahiti coral reef would have been $33 \mathrm{~m}$ above the sea level 14,300 years ago.

Barbados is located in a subduction zone, which was also active throughout the GIA [25]. It is likely that 14,000 years ago the sea bottom was lowered by local tectonic movements. Even though Tahiti is taken to be tectonically a quiet area, it is likely that 14,300 years ago the sea bottom was lowered by a local tectonic movement as well.

MWP-1B cannot be confirmed with the measurements in Tahiti [26]. It was more or less related to the Barbados area. Then the sea bottom there was likely lowered a second time.

Subsequently, the MWP-1A and MWB-1B measurements do not prove the rise of the global sea level. The presumption of the $120 \mathrm{~m}$ rise is vastly exaggerated. The present estimates of the global glaciated area and the thickness of the glaciers during the GIA based on the 
supposed $120 \mathrm{~m}$ rise are vastly exaggerated as well. It is commonly presumed that all continental ice sheets would be 2 to $3 \mathrm{~km}$ thick, and that their weight would have pressed down the ground beneath. As the glaciers melted, the granite crust would have then started to recover their "original" height. This means that granite would have a rather sensitive and reversible elastic modulus. Elastic modulus of granite is 10 to $70 \mathrm{GPa}$ [27] or $1-7 \times 10^{9}$ at (technical atmosphere), rather insensitive and rather irreversible. The thickness of the continental ice layer needs to be 1,000 to $7,000 \mathrm{~km}$ before it would have some effect on the granite in terms of its elasticity.

Much of the earliest (14,550 years ago) record of human habitation in beaches of Florida lies submerged and buried in unique depositional settings. On the riverbank of the Aucilla River a settlement has been found at the depth of 9 $\mathrm{m}$ [28]. This suggests that the sea level rose by 10 to $15 \mathrm{~m}$ when the GIA glaciers melted.

The MWP-3 may be related to the melting of ice. In the Cyclades Islands in Greece, 6,000-year-old beach rock was found at a depth of $4.3 \mathrm{~m}$ [29]. Along the northern coast of Rio Grande do Norte, in northeastern Brazil, the age of beach rock $3 \mathrm{~m}$ below the sea level was 7,000 cal BP [30]. A plausible explanation would be a global sea level rise over several thousand years after the end of the GIA.

\section{Materials and Methods}

\subsection{Aims of the Study}

The aim of this meta-study is to provide an understanding of the events which slowly ended the Great Ice Age (GIA) and initiated the formation of the Sahara Desert.

\subsection{Methods of Study}

The methods of this study are literature studies, present temperature observations and deductions.

A comparison of coastal water and air temperature data [31-34] across the North Atlantic Ocean within the Saharan latitudinal range will demonstrate the importance of the cold return waters by the North Atlantic Undercurrent (NAUC) for the existence of the Sahara Desert.

The young age of the Sahara Desert (around 6,000 years) is demonstrated by citing paleontological, paleobiological, and paleohydrological studies in the literature.

The existence of the Green Sahara during the GIA is argued for the fact that return waters at the time arriving to the Northwest African coast were warmer than they are today. Subsequently, the Saharan area would have received more moisture than it does today.

The thick salt layer at the bottom of the Gulf of Mexico is used to demonstrate that the gulf has long been an inland sea. During the GIA there needed to be a land bridge in the Yucatan Channel separating the Gulf of Mexico from the Atlantic Ocean, preventing the GSC from flowing in their present route.

As evidence of the earthquake which is supposed to have destroyed the land bridge, this article will use the MWP-1B (11,300 years ago). The literature data show that the GIA ended around 11,500 years ago in Europe, and the writings of Plato in which he described the sinking of a continent 11,600 years ago.

The rise of the sea level shown by the beach rock studies will be used as evidence of the slow melting of grounded and floating sea ice, and continental ice sheets. Only after that were the NAUC waters able to flow in full strength to upwell into the beaches of Northwest Africa, desiccating the air entering the Sahara.

Based on this evidence, it is deduced that the flow route of the Great Ice age Gulf Stream (GIA-GS) radically changed and ended the GIA.

\section{Discussion}

\subsection{Turning the Green Sahara into Desert during the Holocene}

\subsubsection{The Sahara Desert}

The Mid-Sahara Rise consists of rugged mountain ranges and plateaus with vast gravel plains (hammada) that have an average elevation of $900 \mathrm{~m}$. Otherwise, most of the Sahara is a low-lying plateau area with an average elevation of $500 \mathrm{~m}$ (see Figure 1). Relatively small areas lay below sea level. The movement of sand by winds has concentrated the sand desert mainly around the periphery of the Sahara leaving the central mountainous areas free of sand accumulation of any size. Sand desert dunes (erg) comprise one fifth of the Saharan area $[1,35]$.

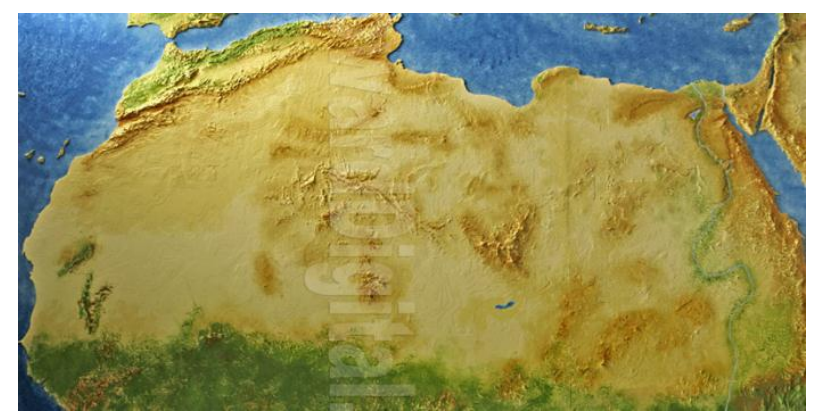

Figure 1. Topographic map of Sahara Desert [36]

The sand seas of the Sahara are open regional deposition centers that receive the sand at their northern or northeastern edge and lose their particles at their southern or southwestern edge. The sand dunes flow in chains.

In the most western part from southeast Cap Juby, near Tarfaya, to southeast Cap Blanc, the barchans reach a 
height of $15 \mathrm{~m}$ (average of 6 to $10 \mathrm{~m}$ ). The maximum width from the end of one wing to the end of the other is $75 \mathrm{~m}$ (average of 15 to $35 \mathrm{~m}$ ). The rocky surface is favorable to saltation. The current barchans achieve an average speed of 25 meters per year. The size of the grains has a median of $220 \mu \mathrm{m}$. Sand particles smaller than $100 \mu \mathrm{m}$ in diameter are ejected into the atmosphere as dust [37].

The export of airborne dust from the desert is huge. Annually, an average of 182 million tons (at the level of $15^{\circ} \mathrm{W}$ ) is carried west by the wind [38]. Sirocco winds bring some dust to southern Europe, and about 25 million tons is annually carried east as well [39].

\subsubsection{Desiccation of Air by Cold Sea Water and by Airborne Dust}

Between $34^{\circ} \mathrm{N}$ to $20^{\circ} \mathrm{N}$, the seawater on the shores of the Sahara Desert is cold compared to the ambient sea water temperature farther away at the sea (see Figure 2). South of $20^{\circ} \mathrm{N}$, the cold surface water is not necessarily the primary reason for the drying of the air as it enters the Sahara/Sahel area from the Atlantic Ocean. An important additional reason for the drying is likely the airborne sand dust.

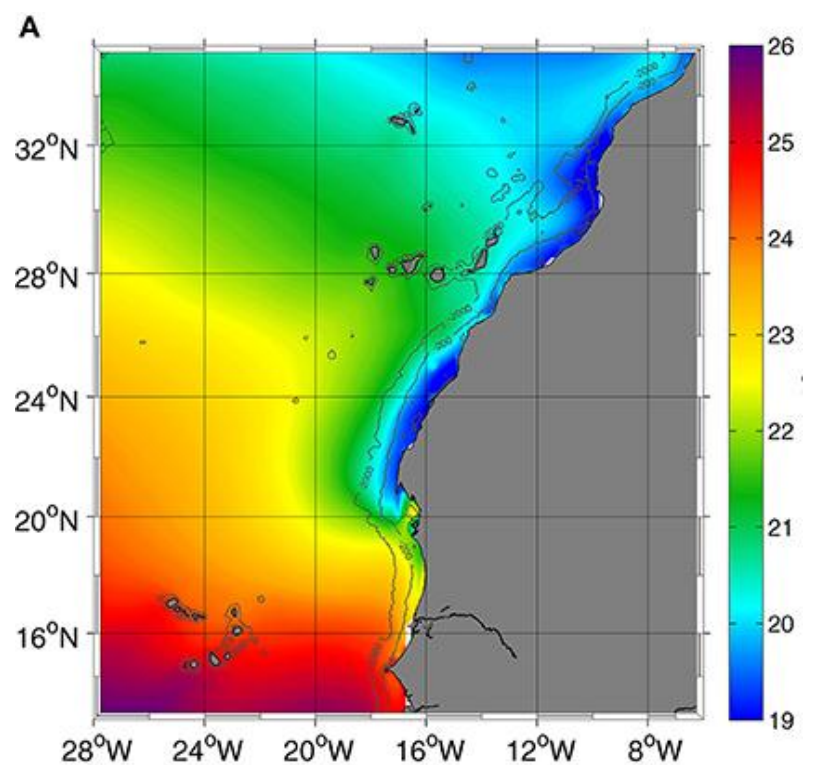

Figure 2. Mean sea-surface temperature along the northwest African coast [47]

The drain droplets start to grow by both homogeneous and heterogeneous nucleation, with the latter being much more effective by several orders of magnitude. As the droplets grow further due to the process of condensation, they start to absorb small particles (which acted previously as the condensation nuclei) in the process known as cloud scavenging [40].

In the Northwest African region, during the dry season months (November to March), the southeast trade winds blow across the Sahara Desert towards the Gulf of Guinea. During this period, the deposition of Saharan mineral dust (SMD) aerosols is so massive that the atmosphere is opalescent even in the coastal areas of the Gulf of Guinea.
Locally, this dusty wind phenomenon is called the Harmattan [41]. The largest concentrations aloft occur where dust loading at the surface is the greatest - between $10^{\circ} \mathrm{W}$ to $10^{\circ} \mathrm{E}$ and $15^{\circ} \mathrm{N}$ to $20^{\circ} \mathrm{N}$ [42]. During winter the wind is carrying the SMD aerosols to the Amazonas [43].

During summer, the African Easterly Jet (AEJ), at a height of $3 \mathrm{~km}$, reaches its zenith between $12^{\circ} \mathrm{N}$ to $17^{\circ} \mathrm{N}$. During October and November, the AEJ weakens and drops southward [44]. As the AEJ and southwest trade winds meet, the resultant wind path is directed west.

As the dust is driven out over the Atlantic Ocean, inversion occurs and SMD aerosols are lifted above the denser marine air [45]. The Saharan Air Layer (SAL) is characterized as a warm dusty layer aloft around 700 to 600 $\mathrm{mb}(3,000$ to $4,300 \mathrm{~m})$ [42], which is known for transporting SMD aerosols across the Atlantic Ocean, even to the Antilles [46].

In 1907, a group of French scientists was appointed to observe the condition of the forests in the French West African colonies. The group concluded: "The forest is shrinking in the whole area, and between Goumbou and Timbuktu it is in the process of completely disappearing" [19]. Today Timbuktu is more or less sand desert area.

A combined consequence of the advancing Saharan sand seas and desiccation by airborne dust is the ongoing, clearly measurable desertification of the Sahel Area.

\subsubsection{Paleobiological and Paleohydrological Evidence of the Green Sahara}

Observations of the ancient Tamanrasset River system [11] demonstrate that the West Sahara received significant precipitation during the GIA. This would imply that then the Atlantic waters on the Northwest African coast were much warmer than they are today. They did not desiccate the sea air entering into the Saharan area.

A 7-million-year-old sand dune deposit has been found in the northern Chad Basin, in the middle of the Sahara Desert [48]. However, this does not necessarily imply that all 9.1 million $\mathrm{km}^{2}$ of the Sahara would have been desert since the Upper Miocene. Small deserts can form even in rather unlikely environments. For example, in Northwest Brazil there is a small desert called the Lençóis Maranhenses [49] and in Canada the Athabasca Sand Dunes [50]. Even the $600,00 \mathrm{~km}^{2}$-Patagonian Desert is small compared to the Sahara. It is likely that outside the desert in the Chad basin there have been large areas where the precipitation has been greater than it is today. Most of the Saharan area has likely been "green".

Biomes for Africa have been mapped for 6,000 cal BP. Madagascar along with eastern, southern and central Africa show only minor changes in terms of biomes, compared to the present. Major changes in biome distributions occur north of $15^{\circ} \mathrm{N}$, with steppe in many low-elevation sites that are now desert, and temperate xerophytic woods/scrub and warm mixed forest in the Saharan mountains. These shifts in biome distributions (from woodland and savannah into 
desert) imply a significant decrease of precipitation between 6,000 years and the present [10]. The drying of the Green Sahara has taken place during the latter half of the Holocene.

\subsubsection{Paleontological Evidences of the Speed of Drying}

At the early Holocene, there were stone age settlements over large areas which are now inhospitable.

Between 5300 and $3500 \mathrm{BC}$, prehistoric settlers began to withdraw from the Western Desert of Egypt, which, due to aridity, became increasingly hostile to man. After $3500 \mathrm{BC}$, the Western Desert of Egypt (outside the oases) seems to be almost void of human occupation [51].

The remains of both terrestrial and aquatic animals retrieved during the excavation of the Takarkori rock shelter (Tadrart Acacus desert, $24^{\circ} 50^{\prime} \mathrm{N} 10^{\circ} 20^{\prime} \mathrm{E}$ in Libya), illustrate the more humid climatic conditions in the Sahara of southwestern Libya during early and middle Holocene times. The material was abundant, consisting of 17,551 identifiable remains, and covered a period between 10,200 and 4,650 cal BP. In the Late Acacus period (10,200 to $8,000 \mathrm{cal} \mathrm{BP}$ ), fish remains represent around $90 \%$ of all the remains. Interestingly, this proportion continues to be robust (80\%) until the Middle Pastoral 1 (6,400 to 5,600 cal $\mathrm{BP})$ and it then drops in the Late Pastoral phase $(5,900$ to 4,650 cal BP) when fish constitute only about $48 \%$ of the remains [52].

Gobero is located in Nigeria in the Ténéré desert region, on the northwestern rim of the Chad Basin, approximately $150 \mathrm{~km}$ southeast of the Air massif $\left(17^{\circ} \mathrm{N} 9^{\circ} \mathrm{E}\right)$. Sereno et al. [53] discovered approximately two hundred human burials in the location on the edge of a paleolake.

The early Holocene occupants at Gobero (7700 to 6200 $\mathrm{BC})$ were largely sedentary hunter-fisher-gatherers with lakeside funeral sites that include the earliest recorded cemetery in the Sahara. Gobero was then abandoned for one millennium. More gracile humans arrived in the mid-Holocene (5200 to $2500 \mathrm{BC}$ ), employing a diversified subsistence economy based on clams, fish, and savanna vertebrates as well as some cattle husbandry [53]. Between 5300 and $2500 \mathrm{BC}$, the uninhabited desert area moved over 2,000 km west from the Nile river.

\subsection{Flow of the Present Day GSC}

The general circulation of the present-day Gulf Stream Currents in the North Atlantic Ocean is depicted in Figure 3.

The volume transport of the Yucatan Current $(\mathrm{YuC})$ is approximately $24 \mathrm{~Sv}$ into the Gulf of Mexico [54]. The volume transport of the Florida Current (FloC) at the transect from Miami to Bimini $\left(25.7^{\circ} \mathrm{N}\right)$ ranges from an early winter low of $25.4 \mathrm{~Sv}$ to a summer high of $33.6 \mathrm{~Sv}$, the average being $29.5 \mathrm{~Sv}$ [55]. Some of the north branch of the North Equatorial Current (nNEC) water via the Antilles Current (AntC) south of the Andros Island joins the flow.
At $27^{\circ} \mathrm{N}$, the mean transport for the FloC is $32.3 \pm 3.2 \mathrm{~Sv}$. It is obvious that $2.9 \mathrm{~Sv}$ more of the nNEC water via the AntC north of the Andros Island reaches the FloC. The mean northward heat flux via the $\mathrm{FloC}$ is then $1.30 \pm 0.13$ PW [56].

Between $27^{\circ} \mathrm{N}$ and $29^{\circ} \mathrm{N}$, the total transport of the FloC increases additionally by approximately $3 \mathrm{~Sv}$, while the current broadens by about 50\%. By then also the Sargasso Sea Circulation (SSC) water starts to reach the FloC. Above $29^{\circ} \mathrm{N}$, the contribution of the SSC water increases. At Cape Hatteras $\left(35^{\circ} 24^{\prime} \mathrm{N}, 75^{\circ} 29^{\prime} \mathrm{W}\right)$, the FloC transport has increased nearly threefold to $93.7 \mathrm{~Sv}$ [57]. It is obvious that the AntC is the driving force for the southsouthwestern section of the SSC flow.

The FloC follows the shelf break of the southeastern United States to Cape Hatteras, where it separates abruptly from the continental margin and proceeds northeast. The Gulf Stream sensu stricto is part of the GSC chain from Cape Hatteras to the southeast edge of the GBN. The single flow bed of the Gulf Stream is characterized by wavy perturbations known as Gulf Stream meanders and eddies. The main momentum of flow is northeast. However, some warm water is transported northward and some cold water southward in so-called Gulf Stream "rings" [58]. An amplitude-related dispersion relation is observed in region from $75^{\circ} \mathrm{W}$ to $45^{\circ} \mathrm{W}$ [59].

In the Arctic Ocean, the seawater carried by the Irminger Current (IrmC), Norwegian Atlantic Current (NwAC), and its branches the North Cape Current $(\mathrm{NCaC})$ and West Spitsbergen Current (WSC) [7] are frozen. Then the salt in the ice crystalline lattice dissolves within liquid inclusions of brine. As this brine is progressively drained (brine rejection), the ice desalinates. Due to the brine ejection, the salinity and the density of the surface water under the ice increases. This decreases the freezing point of the sea water to $-2{ }^{\circ} \mathrm{C}$. Winds (waves) do not mix the water under the ice, so the salt gradient has time to grow to the point that the saline water starts to descend by gravity. Here this water is called descending salty water (DSW) [7].

In the Arctic Ocean, the DSW forms the East Siberian Shelf Undercurrent (ESSUC) and the Barents Sea Undercurrent (BSUC). The East Greenland Current (EGC) flowing into the Labrador Sea is the continuation of the ESSUC. In the North Atlantic Ocean, the BSUC branches to a southbound branch $\left(\mathrm{BSUC}_{\mathrm{S}}\right)$ and a westbound branch (BSUCw). BSUC $\mathrm{W}_{\mathrm{W}}$ flows into the Labrador Sea and $\mathrm{BSUC}_{\mathrm{S}}$ flows into the West European Basin [7].

A surface buoy drifting at a depth of $10 \mathrm{~m}$ was released in the Denmark Strait above the EGC. It was floated into the Labrador Sea and thereof ultimately to the NwAC [60]. This implies that the momentum of the Gulf Stream water transported over the GBN is determining an eastbound direction for the surface currents in the Labrador Sea from the axis of a few hundred kilometers south of Cape Farwell-GBN.

Another buoy drifting at a depth of $75 \mathrm{~m}$ was released in 
Denmark Strait into the shelf break East Greenland Current (sEGC). It was ultimately floated into the West Greenland Current (WGC) [60]. This implies that sEGC is also participating in the confluence (CFL) with the $\mathrm{BSUC}_{\mathrm{W}}$ and the westbound branch of the Irminger Current $\left(\operatorname{IrmC}_{\mathrm{W}}\right)$ southeast from Cape Farwell over the Greenland continental shelf (see Figure 3) [7].

In the Labrador Sea, the southwest-flowing EGC meets the southeast flowing LabC in front of the GBN. The main part of the deep-core EGC water is diverted southeast by the GBN and joins the deep core of the LabC. Together, they form the North Atlantic Undercurrent (NAUC) bound southeast to the coast of Northwest Africa.

Some of the EGC deep-core water also pushed southwest through the Flemish Cap in the GBN, taking with it some of the LabC deep-core water [7].This flow on the eastern slope of the GBN is traditionally named as the offshore branch of the LabC, having an average flow of 4.1 Sv relative to 100 dbar [61]. Here it is called the south-bound Labrador Current $\left(\mathrm{LabC}_{\mathrm{S}}\right)$, even though it equally well could be named south-bound EGC $\left(\mathrm{EGC}_{\mathrm{S}}\right)$. Waters in the Mid-Atlantic Bight have connection to the waters in the East Siberian Shelf. Ultimately, the flow of the $\mathrm{LabC}_{\mathrm{S}}$ extends to Cape Hatteras [62].

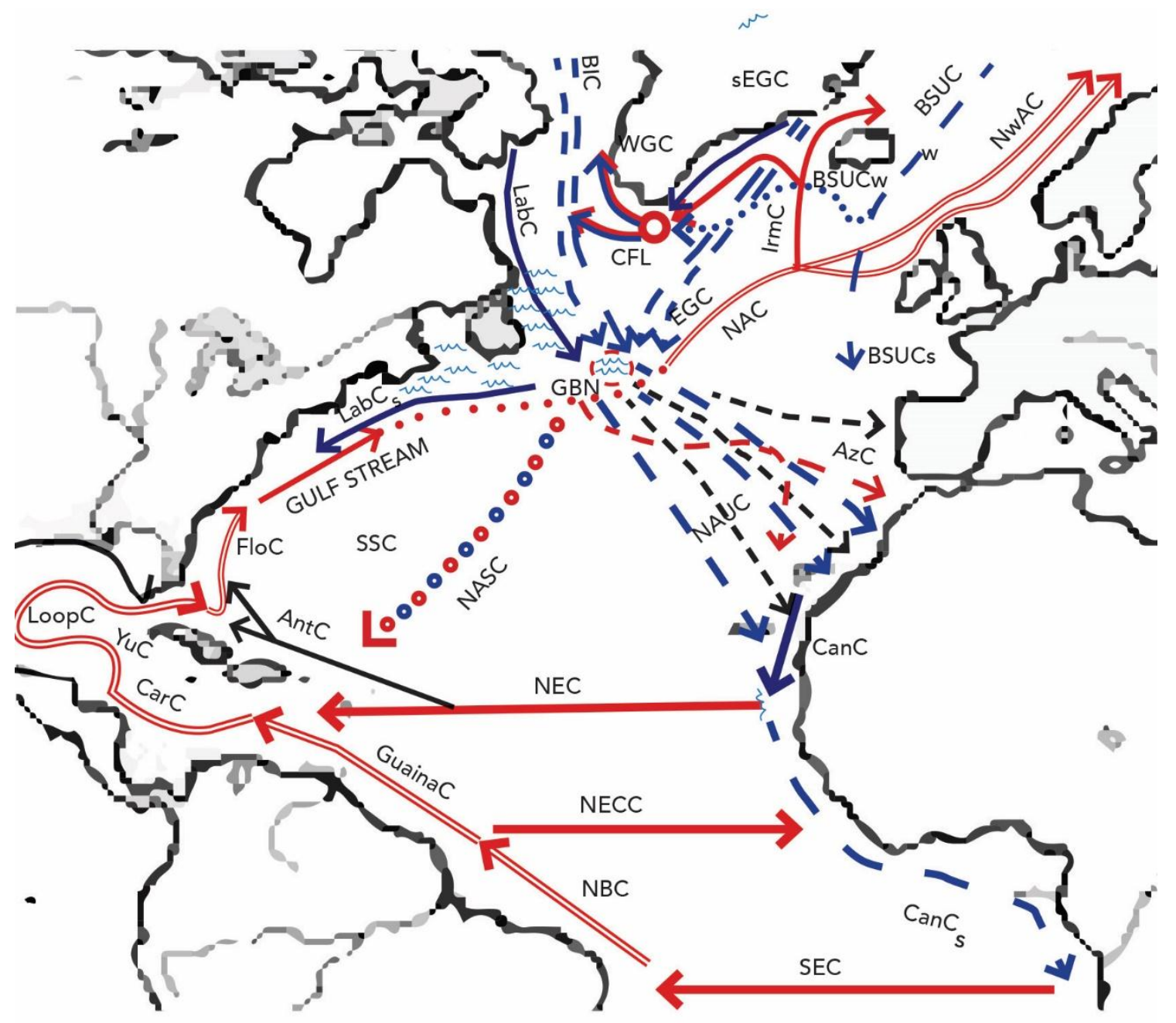

Figure 3. The present circulation of the Gulf Stream Current in the North Atlantic Ocean. See List of Abbreviations for explanations of names of the currents 
In front of the GBN, some of the EGC deep-core water is forced to upwell. The flow continues southwest over the GBN, taking with it some LabC water. This combined flow southeast can be named the North Atlantic Surface Current (NASC). When this flow encounters the Gulf Stream, it forces the Gulf Stream to meander, and the Gulf Stream rings are formed. The driving force for NASC is the kinetic energy obtained by the DSW in the Arctic Ocean. NASC forms the northeastern section of the SSC. Two thirds of the FloC flow at Cape Hatteras is in a water layer with temperatures between 17.0 and $19.5{ }^{\circ} \mathrm{C}$, colder by $7{ }^{\circ} \mathrm{C}$ than the "still" water temperature found at $27^{\circ} \mathrm{N}$ [57]. The SSC is therefore a consequence, not a reason, that the GSC are flowing along their present route.

Once the Gulf Stream has passed the GBN, the NASC no longer interferes with the flow. Subsequently, the flow bed structure of the North Atlantic Current (NAC) becomes multiple, branching fronts, and the flow volume is reduced to 35 to $38 \mathrm{~Sv}$.

\subsection{Effects of the Upwelling of NAUC Water}

On the route of NAUC from the Labrador Sea to the coast of Northwest Africa, there are no major confluences with warm currents. In addition to Azores Current $(\mathrm{AzC})$ water, the upwelled NAUC water is a major contributor to the Canary Current (CanC), which finally returns the compensation water to the starting point of the NEC [7].

By comparing the areas of the Sahara Desert and the Namib Desert, the climatic effects of the NAUC waters are more conspicuous than those of the BenC. In addition to the parallel flow with the South African west coast, the confluence of the BenC with the Agulhas Current mitigates the coldness of the BenC water [7]. The NAUC water is colder than the BenC. NAUC water is also more plentiful than BenC water.

$\mathrm{CanC}_{\mathrm{S}}$ is a transporting part of the NAUC water into the South Equatorial Current (SEC). It is returning the water which the North Brazil Current (NBC) is bringing north balancing the water budgets between the North and South Atlantic Oceans but same time creating imbalanced heat budgets. This contribution is cooling the SEC so much that in the South Atlantic Ocean hurricanes are extremely rare [63].

The most important upwelling area of the NAUC is between the cities of Nouadhibou and Agadir. The water temperature on the coast of Nouadhibou is in March $18^{\circ} \mathrm{C}$ and in September $24^{\circ} \mathrm{C}$ [32]. At the same time, on the coast of Puerto Rico the temperatures are 25 and $28{ }^{\circ} \mathrm{C}$ respectively [33].

The lowering effect of the cold water to the coastal air temperature is high as well. The summer temperature (April to September) is approximately $4.5^{\circ} \mathrm{C}$ colder on the Northwest African coast between Nouadhibou and Agadir than on the Mexican and American coasts between Cancun and Jacksonville (see Table 1).

From August to October, the rainfall is the greatest in the Nouadhibou [34], implying the importance of the seawater temperature for precipitation. Even though the islands of Lanzarote and Fuerteventura only partially prevent the upwelling of NAUC water on the El Aaiún (Laâyoune) coast, the air temperature in summer is higher there than in Nouadhibou, which is located $800 \mathrm{~km}$ south from El Aaiún. This emphasizes the importance of NAUC upwelling waters for the sea and atmospheric temperature on the Saharan coast.

Table 1. Average summer and winter temperatures between $20^{\circ} \mathrm{N}$ to $34^{\circ} \mathrm{N}$ along the coasts of northwestern Africa, eastern Mexico and southeast USA

\begin{tabular}{|c|c|c|c|c|c|c|c|c|}
\hline & $\begin{array}{c}\text { Cancun, } \\
\text { Mexico, } \\
21^{\circ} 10^{\prime} \mathrm{N}, \\
86^{\circ} 51^{\prime} \mathrm{W}\end{array}$ & $\begin{array}{c}\text { Tampico, } \\
\text { Mexico, } \\
22^{\circ} 17^{\prime} \mathrm{N}, \\
97^{\circ} 52^{\prime} \mathrm{W}\end{array}$ & $\begin{array}{c}\text { Melbourne, } \\
\text { FL, } \\
28^{\circ} 4^{\prime} \mathrm{N}, \\
80^{\circ} 39^{\prime} \mathrm{W}\end{array}$ & $\begin{array}{c}\text { Jacksonville, } \\
\text { FL, } \\
30^{\circ} 19^{\prime} \mathrm{N}, \\
81^{\circ} 40^{\prime} \mathrm{W}\end{array}$ & $\begin{array}{c}\text { Noadhibou, } \\
\text { Mauritania, } \\
20^{\circ} 56^{\prime} \mathrm{N}, \\
17^{\circ} 02^{\prime} \mathrm{W}\end{array}$ & $\begin{array}{c}\text { Dakhla, } \\
\text { Western Sahara, } \\
23^{\circ} 41^{\prime} \mathrm{N}, \\
15^{\circ} 57^{\prime} \mathrm{W}\end{array}$ & $\begin{array}{c}\text { El Aaiún, } \\
\text { Western } \\
\text { Sahara, } \\
27^{\circ} 08^{\prime} \mathrm{N}, \\
13^{\circ} 11^{\prime} \mathrm{W}\end{array}$ & $\begin{array}{c}\text { Agadir, } \\
\text { Morocco, } \\
30^{\circ} 24^{\prime} \mathrm{N}, \\
9^{\circ} 36^{\prime} \mathrm{W}\end{array}$ \\
\hline Winter & +24.6 & +22.2 & +20.3 & +16.7 & +21.6 & +19.7 & +19.7 & +17.0 \\
\hline Summer & +27.7 & +27.9 & +26.3 & +25.6 & +23.2 & +21.0 & +23.5 & +21.3 \\
\hline
\end{tabular}




\subsection{Route of the Gulf Stream during the GIA}

During the GIA, the North Sea would have been covered by grounded ice. A necessary requirement for that was that the Gulf Stream sensu stricto did not flow at that time. This, on the other hand, also means that the FloC, NAC, IrmC, NwAC and SSC were not flowing along their present route.

The trade winds are an unstoppable phenomenon. Two corollaries are included: (1) the removal of water from the African coast by the NEC, and (2) the existence of a return current to provide the compensating water for the NEC are unstoppable phenomenon as well. During the GIA, the route of the NEC has been more or less the same as today: the starting point was between $10^{\circ} \mathrm{N}$ to $20^{\circ} \mathrm{N}$ in the Northwest African coast, but the route of the return current, the Great Ice Age Gulf Stream (GIA-GS), differed from the present-day route of the Gulf Stream.

\subsubsection{Salt Deposit in the Gulf of Mexico}

Salt deposits lie under the Gulf of Mexico and the southern United States as far north as Arkansas. At their thickest, these deposits are $8 \mathrm{~km}$ deep. They form two chunks: the Louann Salt layer stretching from Arkansas to the northern Gulf of Mexico, and the Campeche layer, which starts at the base of the Yucatan peninsula and runs up the middle of the Gulf [64-66].

The average depth of the Gulf of Mexico is at present 1.6 $\mathrm{km}$. The deepest point is the Sigsbee Deep, with a depth of about 4,400 m. Originally, the Gulf of Mexico was very deep, likely comprising an ocean trench as well. In addition to salt accumulation, a gradual seafloor subsidence may also have contributed to its formation [67]. Without salt deposits, the Gulf of Mexico might extend up to Arkansas.

The accumulation of a salt layer that is $8 \mathrm{~km}$ thick requires the Gulf of Mexico to have been an inland sea for millions of years. The Yucatan Channel was then needed to be cut by a land bridge. River discharges flowing into the Gulf have partially evaporated, during which salt has accumulated, and partially flowed into the Atlantic Ocean via the Straits of Florida, preventing the discharge of the Atlantic water into the Gulf of Mexico.

A virgin stream emerging from a mountain watershed may contain as little as $50 \mathrm{ppm}$, or $0.05 \%$ of total dissolved solids [68]. The Salar de Uyuni is located at an altitude of $3,600 \mathrm{~m}$ on the Altiplano, a plateau in the south of the Bolivian Andes. It has a surface area of about $10,000 \mathrm{~km}^{2}$. The basin is hydrologically closed, so it receives water only from rainfall and river inflow but does not have any outflow except evaporation and probable seepage into deeper layers. Siedland [69] determined the ${ }^{14} \mathrm{C}$-age of that salt layer to be $12,400 \mathrm{BP}$ at a depth of $7.6 \mathrm{~m}$. Generating this layer of salt would require the accumulation of $0.6 \mathrm{~mm}$ of salt a year. At this rate, an 8-km layer of salt in the Gulf of Mexico would have developed within 14.4 million years.

The precipitation in the watershed areas from which rivers were running into the Gulf of Mexico has been greater than it is today (see section 3.4.3). The accumulation of the salt and sediment has definitively been greater than that in the Lake Titicaca watershed in the Altiplano. However, the overflow via the Straits of Florida has reduced the salt remaining in the Gulf and the possible subsidence of the sea floor increased the demand of salt. These processes extended the time interval during which the 8-km layer of salt has been accumulated. The accumulation of salt may have begun already then when the Caribbean plate was formed.

\subsubsection{Earthquake between 11,300 to 11,600 Years Ago in the Caribbean Arc}

The motion causing the creation of the Caribbean Plate began in the Late Cretaceous to Eocene ( 85 to $45 \mathrm{Ma}$ ). Since that time, it has been a geologically active area. Rapid tectonic arrangements should be the rule, rather than the exception, in the Mesozoic-Tertiary oceanic evolution of the Caribbean arc [70].

According to paleobiological evidence, the temperature in Europe started to rise around 11,500 years ago [71]. Due to the warming, the precipitation increased in Greenland [72]. This can be taken as evidence that the GSC started to flow north at that time, carrying warm water with it. It is likely that during those times there was an earthquake in the Caribbean arc, due to which the Yucatan land bridge collapsed. Measurements related to the MWP-1B can be taken to demonstrate that around 11,300 years the sea floor near Barbados fell.

Historical evidence of the earthquake can be seen in the writings of Plato. In his dialogues Timaeus and Critias, he describes a continent as Atlantis that would have sunk around 11,600 years ago. People which managed to escape disseminated the news around the Mexican Gulf area.

During the GIA, the human habitation on the Aucilla River practiced Clovis culture [28], which is known in Europe as well. Then the Great Ice Age Gulf Stream (GIA-GS) (see section 3.4.3) formed a convenient route to sail from America to Europe/Africa. People might have used it and brought Clovis culture to Europe. Due to the rising sea level caused by the slowly melting glaciers, people had to abandon their living spaces, which presently are at the depth of $9 \mathrm{~m}$ [28]. It is likely that some inhabitants had moved to Europe/Africa, bringing the memory of the earthquake as a tale of the "sinking of a continent." Plato, for example, took this heritage-based evidence seriously, even though today his writings on this issue are discounted.

In southern Australia, a stone age axe has been found under the volcanic ash of the Budj Bim and Tower Hill volcanoes. By measuring the radioactive decay of ${ }^{40} \mathrm{~K}$ into

${ }^{40} \mathrm{Ar}$ over time, archaeologists have estimated the age of the axe to be 37,000 years. The sudden and simultaneous eruptions of two volcanoes have provided the basis of an ancient Aboriginal tale which is told even today [73]. This heritage-based evidence is counted. 


\subsubsection{The Gulf Stream and NAUC during GIA}

During the GIA, the sea currents in the South Atlantic Ocean were likely more or less the same as they are today. Already then water from the northern branch of the South Equatorial Current (nSEC) was flowing via the North Brazil Current (NBC) into the North Atlantic. This created an unbalanced water budget between the North and South Atlantic Oceans, as is the case today. In the tropical North Atlantic Ocean, the NEC and NBC waters flowed into the Caribbean Sea. The land bridge in the Yucatan Channel diverted the flow back. The outflow of the return water, the GIA-GS, was likely directed via the channels between the Cayman Islands and Cuba, and then via the Windward Passage between Cuba and Hispaniola Islands (see Figure 4).

The AzC can be considered as relict of the GIA-GS. Newton's first law states that an object at rest will stay at rest and an object in motion will stay in motion with the same speed and direction unless acted upon by unbalanced force. No unbalancing forces acted on the flow of the GIA-GS when it was approaching the Northwest African coast. Only the flow volume was drastically limited as the GSC started to flow north via the Straits of Florida.

Large areas, $60 \%$, or $61,400 \mathrm{~km}^{2}$, of the Great Bahama Bank (GBB), are shallower than $5 \mathrm{~m}$ [74]. Due to this, the Bahamas are one of the most recognizable places on Earth for astronauts as large areas of shallow, light blue seas [75]. During the GIA, this area was a dry land forming Greater Bahama Islands (GBI). It was diverting the flow of the possible GIA Antilles Current (GIA-AntC) back. Only a small portion of the GIA-GS flow was directed northeast towards the sea ice line (see Figure 4). The flow did not reduce the sea area covered by the floating or grounded ice.

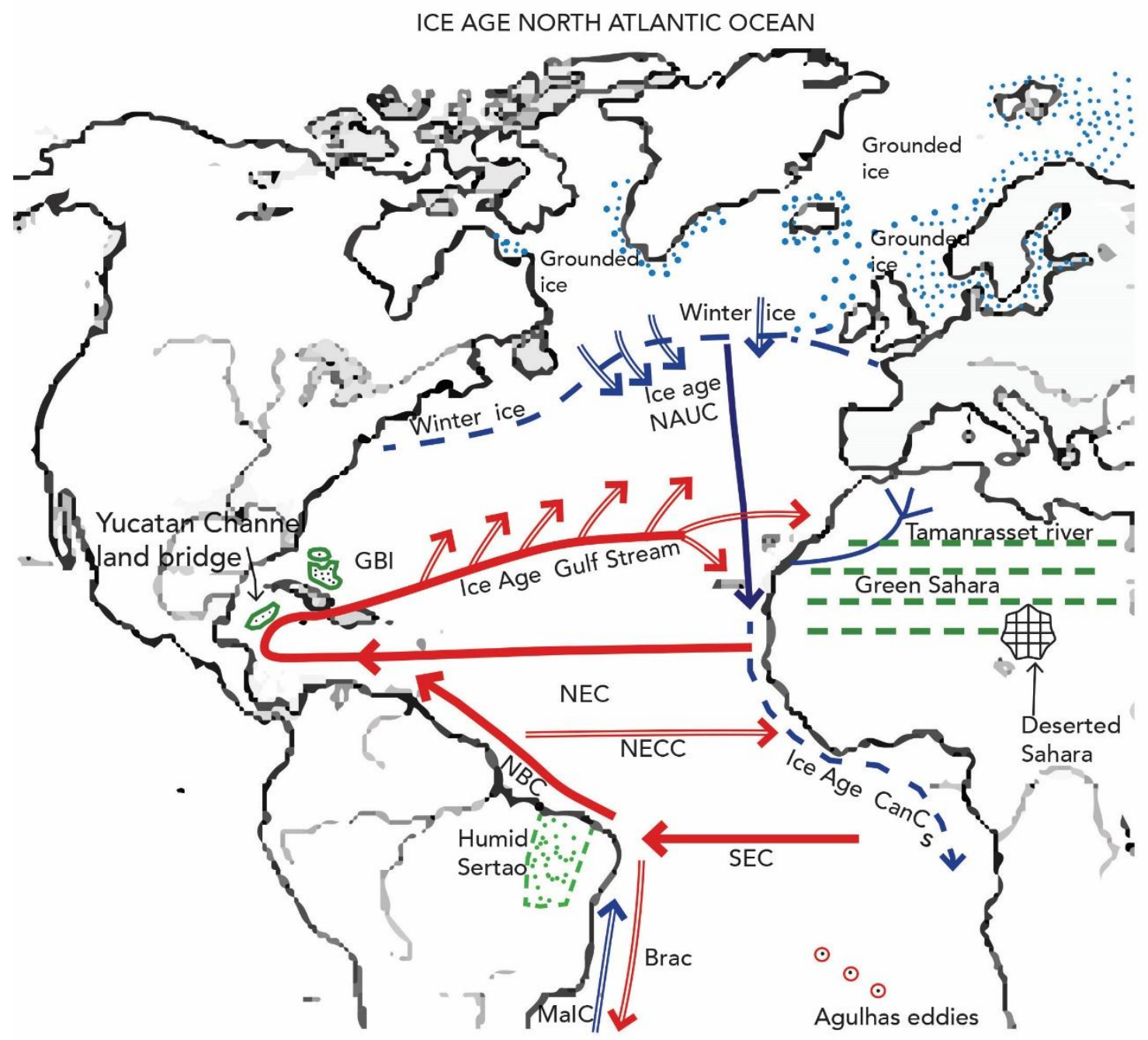

Figure 4. The ocean currents in the North Atlantic during the Great Ice age. See List of Abbreviations for explanations names of the currents 
The winter time sea ice likely extended around $45^{\circ} \mathrm{N}$ on the American coast to $50^{\circ} \mathrm{N}$ on the European coast. During summer, the ice line moved further north. The floating ice layer in the Arctic Ocean and the grounded ice in the Greenland and Iceland continental shelves as well as North Sea prevented the GIA-GS flow further north. The annually freezing and melting amount of sea ice and formation of the DSW was much smaller than it is today. The suction for GIA-GS into the North Atlantic Ocean was small.

The DSW had immediate, free access to the North Atlantic Ocean. It ended up piecemeal to the sea. A focusing suction, like there is now, was not able to develop. The GIA-GS provided the compensating surface water immediately and piecemeal.

The average mass weight center of the piecemeal-forming DSW during the GIA was somewhere between Greenland and Iceland, about 1,500 km more east than where the starting point of the NAUC is today in the Labrador Sea. The flow of the Great Ice Age North Atlantic Undercurrent (GIA-NAUC) would have been directed south by southeast towards the starting point of the NEC. Compared to the present NAUC, the GIA-NAUC had smaller flow volume. A considerable part of its flow was not upwelling on the Moroccan/West Saharan costs. Overall cooling capacity of the GIA-NAUC was low. So, the seawater temperature in coastal Northwest Africa would have been warmer than it is today.

Most of the compensating water for the NEC at the coast of Northwest Africa was provided by the GIA-GS. That is why the NEC waters were warmer already at the starting point than is the case today. The water arriving to Caribbean Sea was warmer as well. Subsequently, due to the higher water and atmospheric temperature the evaporation and precipitation in the Caribbean Sea and Gulf of Mexico likely were higher than they are today.

The GIA-CanC (consisted of waters provided by GIA-GS and GIA-NAUC) would also have been warmer than present-day CanC. The GIA-CanC $\mathrm{S}_{\mathrm{S}}$ returned some water to the northern branch of the South Equatorial Current (nSEC), balancing the water budgets between North and South Atlantic Oceans. Due to this the nSEC waters were warmer at the starting point as well. The heat budgets between the two oceans would have been less unequal than they are today.

During the GIA, the Brazilian Current (BraC) was a warmer current than it is today. Then cooling capacity of that part of the MalC water which went north through the confluence of $\mathrm{BraC}$ vs. MalC [7] was reduced. For this reason, the Sertão was more humid.

Only after the warm water had melted the grounded ice, the $900 \mathrm{~m}$ of floating ice on the Arctic Ocean which was the flow of the NAUC was able to develop to its full strength. The Sahara and Sertão started to dry around 6,000 years ago, which forced the inhabitants to move elsewhere.

\subsection{One Great Ice Age Containing Local Interglacial Periods}

\subsubsection{Validity of the Milankovitch Cycle}

The present understanding is that during the 2.5 million years of the Pleistocene, extensive ice sheets existed in both the northern and southern hemispheres [76]. Numerous global glacial periods, or significant advances of continental ice sheets, are believed to occur at intervals of approximately 40,000 to 100,000 years. The long glacial periods would have been separated by more temperate and shorter interglacial ones [77]. These presumptions are based on the theory of the Milankovitch cycle and the ice core $\delta^{18} \mathrm{O}$ determinations.

Milankovitch believed that of all the orbital cycles obliquity had the greatest effect on climate, especially by varying the summer insolation in the northern high latitudes (shifting geographical latitudes). He calculated these changes and drew a conclusion that the ice ages, as far as their durations were known, seemed to fit his calculations. Therefore, he deduced a period of 41,000 years for ice ages.

When Milankovitch calculated the amounts by which solar radiation changes through orbital variations, he found them to be very small. Most climatologists at the time did not believe them to be large enough to cause such drastic climate changes as were represented by glacial and interglacial periods [78].

Milankovitch made his calculations about the effect of the obliquity change vs. the latitudinal shift along the latitude of $65^{\circ} \mathrm{N}$ (see Figure 5). At this latitude, the maximum change of 2.6 degrees in the obliquity of the earth would mean a latitudinal shift of around 2 degrees north or south (220 to $250 \mathrm{~km}$ ). It is like moving from the level of Yellowknife to the level of Dawson City, or vice versa. For winter temperatures, it would mean a difference of $1.6{ }^{\circ} \mathrm{C}$ and for summer temperatures $1.2^{\circ} \mathrm{C}$ [31]. This kind of change does not trigger any global ice age. The farther below $60^{\circ} \mathrm{N}$ one goes, the more the Milankovitch curve approaches a straight line. Milankovitch's calculations are valid only in the short latitudinal range around $65^{\circ} \mathrm{N}$ and $65^{\circ} \mathrm{S}$.

Criticism of Milankovitch by his contemporaries was justified. The Milankovitch Cycle is not a valid indicator of the global cyclicity of ice ages. The idea of recurrent global ice ages needs a profound reconsideration. 


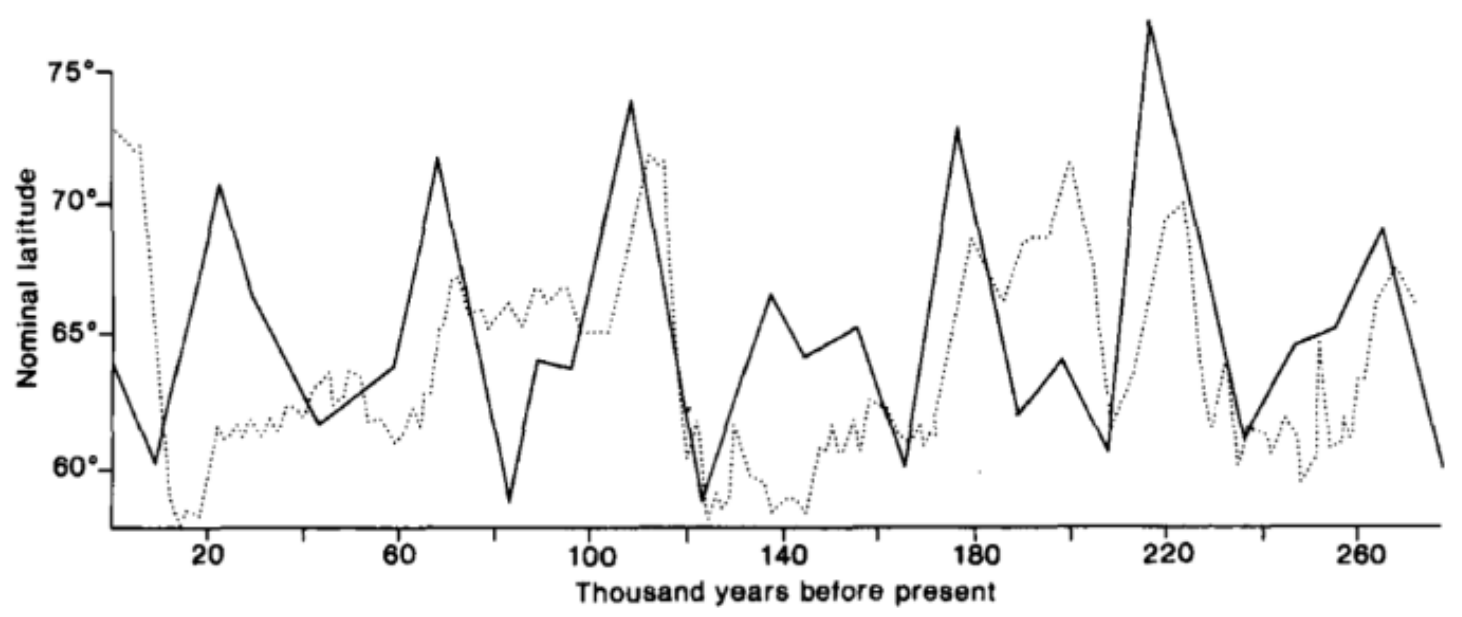

Figure 5. The original Milankovitch curve (solid line) compared with modern isotopic data (dotted line) [78]

\subsubsection{Error Factors in the Ice Core $\delta^{18}$ O Determination}

The most abundant oxygen isotope is the lightest ${ }^{16} \mathrm{O}$ $(99.75 \%)$, the share of the heaviest ${ }^{18} \mathrm{O}$ is $0.20 \%$, and that of the ${ }^{17} \mathrm{O}$ is $0.04 \%$. Hydrogen has two stable isotopes, ${ }^{1} \mathrm{H}$ (99.98\%) and ${ }^{2} \mathrm{H}$ (deuterium, 0.02\%) and radioactive tritium ${ }^{3} \mathrm{H}$ (traces). According to mass numbers and characteristics, nine isotopic configurations have been distinguished for water. However, due to the low abundances of ${ }^{17} \mathrm{O},{ }^{2} \mathrm{H}$ and ${ }^{3} \mathrm{H}$, in practice all water molecules are considered to be isotopic combinations of ${ }^{1} \mathrm{H}_{2}{ }^{16} \mathrm{O}$ and ${ }^{1} \mathrm{H}_{2}{ }^{18} \mathrm{O}[79]$.

Delta values $(\delta)$ of stable isotope ratios of water are conventionally expressed as per mil (\%) deviation from Vienna Standard Mean Ocean Water (VMSOW) [80]. In the air, heavier water molecules containing ${ }^{18} \mathrm{O}$ atoms tend to condense and precipitate first. The water vapor gradient heading from the tropics to the poles gradually becomes more and more depleted of ${ }^{18} \mathrm{O}$. On the ice caps in Greenland and Antarctica relatively more $\mathrm{H}_{2}{ }^{16} \mathrm{O}$ is precipitated as snow. The ratio of ${ }^{18} \mathrm{O}$ to ${ }^{16} \mathrm{O}$ (marked as $\delta^{18} \mathrm{O}$ ) from the ice core samples is used as a proxy to determine the eras of ice ages on Earth [81].

However, in the poles during the continuous 4 to 6 months of summer sunshine, a portion of snow evaporates. Then relatively more $\mathrm{H}_{2}{ }^{16} \mathrm{O}(\mathrm{g})$ is removed, and $\mathrm{H}_{2}{ }^{18} \mathrm{O}$ is subsequently enriched in the remaining snow. This process reverses some of the $\delta^{18} \mathrm{O}$ depletion that occurs on the journey to the poles.

During summers, part of the snow also melts in Greenland and Antarctica. Meltwater digs holes (moulins) in the ice and descends until it is frozen again. The liquid density of $\mathrm{H}_{2}{ }^{16} \mathrm{O}$ is $0.997 \mathrm{~g} / \mathrm{cm}^{3}$, while that of the $\mathrm{H}_{2}{ }^{18} \mathrm{O}$ is $1.106 \mathrm{~g} / \mathrm{cm}^{3}$ [79], and in the meltwater the $\mathrm{H}_{2}{ }^{18} \mathrm{O}$ tends to stratify at the bottom. This process develops layers enriched with $\mathrm{H}_{2}{ }^{16} \mathrm{O}$ or $\mathrm{H}_{2}{ }^{18} \mathrm{O}$. They do not have any causal connection to the atmospheric temperature during that time when the seawater originally evaporated. So, the $\delta^{18} \mathrm{O}$ ratio alone is not a sufficient proxy for the atmospheric changes occurring on the earth.
Additionally, it needs to be observed that the 2- to $3-\mathrm{km}$ ice layers in Antarctica and Greenland do not move monolithically. The higher section of ice moves more rapidly compared to the more bottom sections. That is why a vertical ice core sample does not necessarily indicate the exact chronological history of the ice layer. Even tens of thousands of years may be missing. A skewed cross-section would yield a more exact chronological history.

A further important observation is that due to the smaller glaciated area, the flow of the ice currents in Greenland is more rapid than it is in Antarctica. A more skewed cross-section should be taken in Greenland than in Antarctica for the comparison. The present chronological data in terms of the ice core $\delta^{18} \mathrm{O}$ determination provided from vertical ice core samples are not directly comparable between Greenland and Antarctica.

\subsubsection{Local Interglacial Periods during the GIA}

Locally in Finland, southern Sweden, northern Poland, Latvia and the areas of the Adirondack, White and Laurentian mountain areas, there might have been iceless periods that lasted thousands of years, and which would have allowed the emergence of flora and fauna. These periods within the GIA are known as the interglacial periods (IGP). The dates of IGPs have not necessarily been coincident.

During the IGP, the advancement of a glacier to a certain direction was stopped by friction. In these relatively southern locations, the ambient summer temperatures during the GIA were above zero. Without new input of ice, the glaciers started to melt and recede. Eventually the resistance to the glacier flow was relieved to such an extent that ice started to flow again from the center of the glaciation.

Based on isotope tests dating of the bedrock surfaces using cosmogenic isotopes of ${ }^{10} \mathrm{Be}$ and ${ }^{26} \mathrm{Al}$ [82], it is supposed that a glacial armor has covered the mountains in Svalbard for at least the past one million years [83]. In 
Greenland, Iceland, Novaya Zemlya, Severnaya Zemlya, and Franz Josef Land, where the average summer temperatures were also below zero, the glaciers did not melt. It is also likely that the floating ice layer and shallow sea areas with grounded ice were stable during the whole GIA.

The accumulation of a floating ice layer that was $900 \mathrm{~m}$ thick in the Arctic Ocean may have taken tens of thousands of years, if not even a few hundred thousand years. As the freeboard of the floating ice has been $80 \mathrm{~m}$, the suggested freshening of the entire Arctic Ocean during the GIA [16] may be caused by the bottom melting at a depth of $820 \mathrm{~m}$. The melting has been a slow process. Effective freshening may require millions of years. It is plausible that during the whole Pleistocene and maybe even the entire Neogene era, the North Atlantic Ocean north of 45 to $55^{\circ} \mathrm{N}$ and related terrestrial areas along the present flow route of the GSC were in the GIA.

\section{Conclusions}

The aim of this meta-study was to provide an understanding of the events which slowly ended the Great Ice Age (GIA) and initiated the formation of the Sahara Desert.

At the bottom of the Gulf of Mexico, there is a layer of salt that is $8 \mathrm{~km}$ thick. This suggests that the gulf has been an inland sea for a long period. A land bridge in the Yucatan Channel and an overflow via the Straits of Florida might have separated it from the Atlantic Ocean. The land bridge reflected the flow of the NEC towards the coast of Northwest Africa as the GIA-GS. Its upwelling waters were warm. They did not desiccate the sea air entering the Sahara, which was subsequently "green."

During the GIA, the floating ice layer in the Arctic Ocean and grounded ice in the Iceland and Greenland continental shelves as well as in the North Sea prevented the flow of the GSC into the Arctic Ocean. Related terrestrial areas were covered by thick, sub-zero glaciers.

About 11,300 to 11,600 years ago, an earthquake in the Caribbean plate might have cut the land bridge connecting the gulf to the Atlantic Ocean. This allowed the Gulf Stream Currents (GSC) to occupy the present northern flow route. Within 4,000 to 5,000 years, the grounded ice, floating sea ice and the continental glaciers had melted and the global sea level had risen by 10 to 15 meters. By then the return flow of water carried by the GSC into the Arctic Ocean was also developed first via undercurrents into the Labrador Sea, and then from there to the coast of Northwest Africa as the North Atlantic Undercurrent (NAUC). Its upwelling waters started to desiccated the sea air entering the Sahara

Paleobiological, paleohydrological, and paleontological observations confirm that the drying of the Sahara started in earnest about 6,000 years ago. By then the desertification was advanced so that airborne dust, working as a cloud-seeding agent, started to enhance the drying. Today, the continuing desertification is threatening the Sahel belt as well.

\section{List of Abbreviations}
$\mathrm{ACC}=$ Antarctic Circumpolar Current
$\mathrm{AEJ}=$ African Easterly Jet
AntC $=$ Antilles Current
at $=$ technical atmosphere
$\mathrm{AzC}=$ Azores Current
BenC $=$ Benguela Current
BenCE $=$ Branch of BenC along the African east coast
$\mathrm{BIC}=$ Baffin Island Current
$\mathrm{BraC}=$ Brazil Current
BSUC $=$ Barents Sea Undercurrent
BSUCW = western branch of the BSUC
BSUCS = southern branch of the BSUC
CanC $=$ Canary Current
$\mathrm{CFL}=$ Confluence
DSW $=$ Descending Salty Water
EGC $=$ East Greenland Current
sEGC $=$ shelf break East Greenland Current
ESSUC $=$ East Siberian Shelf Undercurrent
FloC $=$ Florida Current
GBB $=$ Great Bahama Bank
$\mathrm{GBI}=$ Greater Bahama Islands
GBN $=$ Grand Bank of Newfoundland
GIA $=$ Great Ice Age
GIA-AntC $=$ Great Ice Age Antilles Current
GIA-CanC $=$ Great Ice age Canary Current
GIA-GS = Great Ice Age Gulf Stream
GIA-NAUC $=$ Great Ice Age North Atlantic
Undercurrent
GSC $=$ Gulf Stream Currents
IGP = Interglacial period
IrmC = Irminger Current
IrmCW = western branch of the IrmC
LabC $=$ Labrador Current
LabCS = southern branch of the LabC
LoopC $=$ Loop Current
MalC $=$ Malvinas Current
MWP $=$ melt water pulse
NAC $=$ North Atlantic Current
NAUC $=$ North Atlantic Undercurrent
NASC $=$ North Atlantic Surface Current
$\mathrm{NBC}=$ North Brazil Current
$\mathrm{NCaC}=$ North Cape Current
$\mathrm{NEC}=$ North Equatorial Current
$\mathrm{nNEC}=$ northern branch of the North Equatorial Current
NECC $=$ North Equatorial Countercurrent
NwAC $=$ Norwegian Atlantic Current
$\mathrm{PHC}=$ Peru-Humboldt Current
$\mathrm{SAL}=$ Saharan air layer
$\mathrm{SEC}=$ South Equatorial Current 
nSEC $=$ northern branch of the South Equatorial Current

SMD $=$ Saharan mineral dust

SomC $=$ Somali Current

$\mathrm{SSC}=$ Sargasso Sea Circulation

$\mathrm{Sv}=$ Sverdrup

VSMOW = Vienna Standard Mean Ocean Water

WGC $=$ West Greenland Current

WSC $=$ West Spitsbergen Current

$\mathrm{YuC}=$ Yucatan Current

\section{Acknowledgements}

I am very grateful to Matthew Wuethrich from the University of Jyväskylä Language Services for revising the English of the manuscript. I thank my daughter Heidi for the drawing of Figures 3 and 4, and my wife Ritva for her support.

\section{REFERENCES}

[1] M. Williams, Climate Change in Deserts, Cambridge University Press, 2014. ISBN: 978-1-107-016991-01.

[2] en.wikipedia.org/wiki/Atacama_Desert

[3] M. Parra, A. Mora, C. Jaramillo, M. R. Strecker, E. R. Sobel, L. Quiroz, M. Rueda and V. Torres. Eastern Orogenic wedge advance in the northern Andes: Evidence from the Oligocene-Miocene sedimentary record of the Medina Basin, Eastern Cordillera, Colombia. Geological Society of America Bulletin, Vol. 121, No. 5, 780-800, 2009. DOI:10.1130/B26257.1

[4] L. Evenstar, A. Hartley, C. Rice, F. Stuart, A. Mather and G. Chong, Miocene-Pliocene climate change in the Peru-Chile Desert, Extended Abstracts, 258-260, 2005, $6^{\text {th }}$ International Symposium on Andean Geodynamics (ISAG), 12-14 Sept. 2005, Universitat de Barcelona. ISBN: 2-7099-1575-8.

[5] E. D. McKee, Sedimentary structures in dunes of the Namib Desert, South West Africa. Geological Society of America Special Paper No. 188, p. 64, 1982. ISBN-13: 978-0813721880.

[6] P. Vermeesch, C. R. Fenton, F. Kober, G.F.S. Wiggs, C.S. Bristow and S. Xu, Sand residence times of one million years in the Namib Sand Sea from cosmogenic nuclides, Nature Geoscience, Vol 3, 862-865, 2010. www.ucl.ac.uk/ ucfbpv e/papers/VermeeschNatGeo2010/.

[7] K. Hänninen, "Driving Forces and Flow Mechanisms of the Atlantic Ocean Currents," Environment and Ecology Research, Vol. 8, No. 1, 1-28, 2020. DOI: 10.13189/eer.2020.080101.

[8] L. M. Beal, H. L. Bryden, Observations of an Agulhas Undercurrent, Deep Sea Research Part I: Oceanographic Research Papers, Vol. 44, No. 9-10, 1715-1724, 1997. DOI.org/10.1016/S0967-0637(97)00033-2.

[9] J. Arísteguia, E. D. Barton, X. A. Álvarez-Salgadob, A. M. P. Santosc, F. G. Figueiras, S. Kifanid, S. Hernández-Leóna, E.
Masona, E. Machúe and H. Demarcq, Sub-regional ecosystem variability in the Canary Current upwelling, Progress in Oceanography, Vol. 83, 33-48, 2009. doi:10.1016/j.pocean.2009.07.031.

[10] D. Jolly, I. Colin Prentice, R. Bonnefille, A. Ballouche, M. Bengo, P. Brenac, G. Buchet, D. Burney, J. - P. Cazet, R. Cheddadi, T. Edorh, H. Elenga, S. Elmoutaki, J. Guiot, F. Laarif, H. Lamb, A. - M. Lezine, J. Maley, M. Mbenza, O. Peyron, M. Reille, I. Reynaud - Farrera, G. Riollet, J. C. Ritchie, E. Roche, L. Scott, I. Ssemmanda, H. Straka, M. Umer, E. van Campo, S. Vilimumbalo, A. Vincens and M. Waller, Biome reconstruction from pollen and plant macrofossil data for Africa and the Arabian peninsula at 0 and 6000 years, Journal of Biogeography Vol. 25, No. 6, 1007-10279, 1998. DOI.org/10.1046/j.1365-2699.1998.002 38.x.

[11] C. Skonieczny, P. Paillou, A. Bory, G. Bayon, L. Biscara, X. Crosta, F. Eynaud, B. Malaize, M. Revel, N. Aleman, J.-P. Barusseau, R. Vernet, S. Lopez and F. Grousset, African humid periods triggered the reactivation of a large river system in Western Sahara, Nature Communications, Vol. 6, Article no. 8751, 2015. DOI: 10.1038/ncomms9751.

[12] en.wikipedia.org/wiki/Sert\%C3\%A3o

[13] F. M. Santos, G. C. Lessa, M. Cirano, R. M. Domingues and C. A. D. Lentini, Localized coastal upwelling at the Brazil Current formation zone $\left(13^{\circ} \mathrm{S}\right)$. In: Simpósio Brasileiro de Sensoriamento Remoto, 17. (SBSR), 2015, João Pessoa-PB, Brasil. Internet. ISBN: 978-85-17-0076-8.

[14] S. A. Coelho-Souza, M. S. López, J. R. D. Guimarães, R. Coutinho and R. N. Candella, Biophysical interactions in the Cabo Frio upwelling system, southeastern Brazil, Brazilian Journal of Oceanography, Vol. 60, No. 3, 2012. dx.doi.org/10.1590/S1679-87592012000300008109.

[15] E. Boëda, I. Clemente-Conte, M. Fontugne, C. Lahaye, M. Pino, G. D. Felice, N. Guidon, S. Hoeltz, A. Lourdeau, M. Pagli, A.-M. Pessis, S. Viana, A. Da Costa, and E. Douville, A new late Pleistocene archaeological sequence in South America: Vale da Pedra Furada (Piauí, Brazil), Antiquity, Vol. 88, No. 341, 927-941, 2014. antiquity.ac.uk/projgall/b oeda341/.

[16] W. Geibert, J. Matthiessen, I. Stimac, J. Wollenburg and R. Stein, Glacial episodes of a freshwater Arctic Ocean covered by a thick ice shelf. Nature, Vol. 590, 97-102, 2021. DOI: 10.1038/s41586-021-03186-y.

[17] A. Elverhøi. W. Fjeldskaar, A. Solheim, M. Nyland-Berg and L. Russwurm, The Barents Sea Ice Sheet-A model of its growth and decay during the last ice maximum, Quaternary Science Reviews, Vol. 12, No. 10, 863-873, 1993. DOI.org/10.1016/0277-3791(93)90025-H.

[18] www.1843magazine.com/dispatches/dispatches/my-whirlwi nd-tour-of-timbuktu.

[19] T. A. Benjaminsen and G. Berge, Myths of Timbuktu: From African El Dorado to Desertification, International Journal of Political Economy, Vol. 34, No. 1, 31-59, 2014. DOI: 10.1080/08911916.2004.11042915.

[20] A. S. Dennis, Weather Modification by Cloud Seeding, 1980, Academic Press, New York. ISBN: 0-12-210650-4.

[21] S. E. Nicholson, C. Funk and A. H. Fink, Rainfall over the African continent from the $19^{\text {th }}$ through the $21^{\text {st }}$ century, 
Global and Planetary Change, Vol. 165, 114-127, 2018. doi.org/10.1016/j.gloplacha.2017.12.014.

[22]R. G. A Fairbanks, 17,000-year glacio-eustatic sea level record: influence of glacial melting rates on the Younger Dryas event and deep-ocean circulation Nature, Volume 342, Issue 6250, 637-642, 1989. DOI: 10.1038/342637a0.

[23]E. Bard, B. Hamelin, M. Arnolds, L. Montaggionis, G. Cabiochll, G. Faurell and F. Rougerie, Deglacial sea-level record from Tahiti corals and the timing of global meltwater discharge, Nature, Vol 382, 241-244, 1996.

[24] P. Deschamps, N. Durand, E. Bard, B. Hamelin, G. Camoin, A. L. Thomas, G. M. Henderson, J. Okuno, and Y. Yokoyama, Ice sheet collapse and sea-level rise at the Bølling warming 14,600 yr ago, Nature, Vol. 483, 559-564, 2012, DOI: 10.1038/nature10902.

[25]E. Bard, B. Hamelin, P. Deschamps and G. Camoin, Comment on "Younger Dryas sea level and meltwater pulse 1B recorded in Barbados reefalcrest coral Acropora palmata by N. A. Abdul et al., Paleoceanography, Vol. 31, 1603-1608, 2016. DOI:10.1002/2016PA002979.

[26]E. Bard, B. Hamelin, and D. Delanghe-Sabatier, Deglacial meltwater pulse 1B and Younger Dryas sea-levels revisited with new on shore boreholes at Tahiti, Science, Vol. 327, 1235-1237, 2010.

[27] D. D. Pollard and R. C. Fletcher, Fundamentals of Structural Geology, 2005, p. 321, Cambridge University Press, New York. ISBN: 13 978-0-521-83927-0.

[28] J. J. Halligan, M. R. Waters, A. Perrotti, I. J. Owens, J. M. Feinberg, M. D. Bourne, B. Fenerty, B. Winsborough, D. Carlson, D. C. Fisher, T. W. Stafford Jr. and J. S. Dunbar, Pre-Clovis occupation 14,550 years ago at the Page-Ladson site, Florida, and the peopling of the Americas, Science Advance, Vol. 2, No. 5, e1600375, 2016. DOI: 10.1126/sciadv. 1600375 .

[29] S. Desruelles, É. Fouacher, A. Ciner, R. Dalongeville, K. Paviopoulos, E. Kosun, Y. Qoquinot and J.-L. Ptdevin, Beachrocks and sea level changes since Middle Holocene: Comparison between the insular group of Mykonos-DelosRhenia (Cyclades, Greece) and the southern coast of Turkey, Global and Planetary Change, Vol 66, No. 1-2, 19-33, 2009. DOI.org/10.1016/j.gloplacha.200 8.07.009G

[30] L. H. de Oliviera Caldas, K. Stattegger, H. Vital, Holocene sea-level history: Evidence from coastal sediments of the northern Rio Grande do Norte coast, NE Brazil, Marine Geology, Vol. 228, No. 1-4, 39-53, 2006. DOI.org/10.1016/j.margeo.2005.12.008.

[31] The Typical Weather Anywhere on Earth, weatherspark.com.

[32] weather-and-climate.com/average-monthly-water-Temperat ure, Nouadhibou, Mauritania.

[33] C A. Kaye, Shoreline Features and Quaternary shoreline changes, Puerto Rico. In: Coastal geology of Puerto Rica, Geological Survey Professional Paper 317-B, p. 56, 1959. United States Government Printing Office, Washington. ASIN: B003F3MV3I.
[34] weather-and-climate.com/average-monthly-precipitation-Ra infall, Nouadhibou, Mauritania.

[35] geography.name/ahaggar-mountains/.

[36] www.howardmodels.com/0-topographic/landform-maps-mo dels/africa/africa-06.html.

[37] M. Mainguet, Wind Erosion in Africa, a Neglected Creeping or Catastrophic Process of Land Degradation: Suggestions for Control, 13-39, 1988. In: M.V.K. Sivakumar, M.A. Zobisch, S. Koala and T. Maukonen (Eds.). 1998 Wind Erosion in Africa and West Asia: Problems and Control Strategies. Proceedings of the ICARDA/ICRISAT/UNEPNIJIV10 Expert Group Meeting, 22-25 April 1997, Cairo, Egypt. International Center for Agricultural Research in the Dry Areas (ICARDA), Aleppo, Syria. v + 198 pp. ISBN: 92-9127-077-6.

[38]E. Grey, NASA Satellite Reveals How Much Saharan Dust Feeds Amazon's Plants, NASA's Earth Science News Team, NASA's Goddard Space Flight Center, Greenbelt, Maryland, 2017 , www.nasa.gov/content/goddard/nasa-satellite-reveals-howmuch-saharan-dust-feeds-amazon-s-plants.

[39]E. M. Bridges, World Geomorphology p. 36, 1990, Cambridge University Press. ISBN: 0-521-38343-9.

[40] H. R. Pruppacher and J. D. Klett, Microphysics of Clouds and Precipitation. Kluwer Academic Publishers, 2003, ISBN: 0-7923-4211-9.

[41] A. K. Sunnu, G. Afeti and F. Resch, "Daily Levels of the Harmattan Dust near the Gulf of Guinea over 15 Years: 1996-2011," Environment and Ecology Research, Vol. 6, No 6, 593-604, 2018. DOI: 10.13189/eer.2018.060609.

[42] M. P. Marcella and E. A. B. Eltahir, The role of mineral aerosols in shaping the regional climate of West Africa, Journal of Geophysical Research: Atmospheres, Vol. 119, 114, 2014. DOI: 10.1002/2012JD019394, earthobservatory.nasa.gov/images/39014/dust-plumes-off-w estern-africa.

[43] www.climatecentral.org/news/sahara-dust-amazon-rainfores t-nasa-18708

[44] M. Leroux, The Meteorology and Climate of Tropical Africa Springer. pp. 138-139, 2001. ISBN: 978-3-540-42636-3.

[45] en.wikipedia.org/wiki/Saharan_Air_Layer.

[46] earthobservatory.nasa.gov/images/39014/dust-plumes-off-w estern-africa.

[47] M. Gómez-Letona, A. G. Ramos, J. Coca and J. Arístegui, Trends in Primary Production in the Canary Current Upwelling System-A Regional Perspective Comparing Remote Sensing Models, Frontiers in Marine Science, Vol 4 370, 2017. DOI: 10.3389/fmars.2017.00370.

[48] M. Scuster, P. Duringer, J.-F. Ghienne, P. Vignaud, H. T. Mackaye, A. Likius and M. Brunet, The Age of the Sahara Desert, Science, Vol. 311, No. 5762, 821, 2006. DOI: 10.1126/science. 1120161.

[49] en.wikipedia.org/wiki/Len\%C3\%A7\%C3\%B3is_Maranhens es_National_Park. 
[50] J. Billock, See the Most Northerly Active Sand Dunes in the World, 2017,www.smithsonianmag.com/travel/see-most-no rtherly-sand-dunes-world-180964704/.

[51] N. Pöllath, The prehistoric gamebag: The archaeozoological record from sites in the western Desert of Egypt, pp. 79-108. In H. Riemer, F. Förster, M. Herb and N. Pöllath, (Eds.), Desert animals in the eastern Sahara: status, economic significance, and cultural reflection to antiquity. Proceedings of an Interdisciplinary ACACIA Workshop, University of Cologne, December 14- 5, 2007. Colloquim Africanum 4, Köln, Heinrich-Barth Institute, 2010. ISBN: 9783927688360 .

[52] W. Van Neer, F. Alhaique, W. Wouters, K. Dierickx, M. Gala, Q. Goffette, G. S Mariani, A. Zerboni and S. di Lemia, Aquatic fauna from the Takarkori rock shelter reveals the Holocene central Saharan climate and palaeohydrography. PLoS ONE, Vol. 15, No. 2, e0228588, 2020 doi.org/10.1371/journal.pone.0228588.

[53] P. C. Sereno, E. A. A. Garcea, H. Jousse, C. M. Stojanowski, J-F Saliège, A. Maga, O. A. Ide, K. J. Knudson, A. M. Mercuri, T. W. Stafford Jr., T. G. Kaye, C. Giraudi, I. M. N'siala, E. Cocca, H. M. Moots, D. B. Dutheil and J. P. Stivers, Lakeside Cemeteries in the Sahara, 5000 Years of Holocene Population and Environmental Change, PLoS ONE Vol. 3, No. 8, e2995, 2008. doi.org/10.1371/journal.pone.0002995.

[54] J. Sheinbaum, J. Candela, A. Badan and J. Ochoa, Flow structure and transport in the Yucatan Channel, Geophysical Research Letters, Vol. 29, 1040, 2002, DOI:10.1029/2001GL013990.

[55] P. P. Niiler and W. S. Richardson, Seasonal variability in Florida Current, Journal of Marine Research, Vol 31, No. 2, 144-167, 1973.

[56] J. C. Larsen, Transport and heat flux of the Florida Current at $27^{\circ} \mathrm{N}$ derived from cross-stream voltages and profiling data: theory and observations. Transactions of the Royal Society of London A, Vol. 338, No. 1650, 169-236, 1992. DOI: org/10.1098/rsta.1992.0007.

[57] K. D. Leaman, E. Johns and T. Rossby, The Average Distribution of Volume Transport and Potential Vorticity with Temperature at Three Sections across the Gulf Stream, Journal of Physical Oceanography, Vol. 19, No. 1, 36-51, 1989. DOI: 10.1175/1520-0485(1989)0192.0.CO;2.

[58] G. G. Sutyrin, I. Ginis and S. A. Frolov, Equilibration of Baroclinic Meanders and Deep Eddies in a Gulf Stream-type Jet over a Sloping Bottom, Journal of Physical Oceanography, Vol. 31, No. 8, 2049-2065, 2001. DOI: org/10.1175/1520-0485(2001)031<2049:EOBMAD>2.0.CO $; 2$.

[59] T. Lee and P. Cornillon, Propagation and growth of Gulf Stream meanders between $75^{\circ}$ and $45^{\circ} \mathrm{W}$, Journal of Physical Oceanography, Vol. 26, 225-241, 1996. DOI: org/10.1175/1520-0485(1996)026<0225:PAGOGS > 2.0.CO; 2.

[60] J. Uotila and J. Launiainen, An Analysis of Buoy Drift in the Northern Atlantic with Detection of Drogue Loss Events, Atmosphere-Ocean, Vol. 35, No. 4, 471-494, 1997. DOI: org/10.1080/07055900.1997.9649600.

[61] B. Petrie and C. Anderson, Circulation on the Newfoundland continental shelf, Atmosphere-Ocean, Vol. 21, No. 2, 207226, 1983. DOI: 10.1080/07055900.1983.9649165.

[62] M. Andres, M. Muglia, F. Bahr and J. Bane, Continuous Flow of Upper Labrador Sea Water around Cape Hatteras, Scientific Reports, Vol. 8, 4494, 2018. DOI: org/10.1038/s41598-018-22758-z.

[63] earthobservatory.nasa.gov/images/12937/rare-south-atlantic -tropical-cyclone.

[64] J. Frazer, Playing in a Deep-Sea Brine Pool Is Fun, as Long as You're an ROV [Video], Scientific American, June 18, 2015.

blogs.scientificamerican.com/artful-amoeba/playing-in-a-de ep-sea-brine-pool-is-fun-as-long-as-you-re-an-rov-video/.

[65] B. Mason, New Seafloor Map Reveals How Strange the Gulf of Mexico Is, National Geography, 2017. news.nationalgeographic.com/2017/05/new-seafloor-map-g ulf-of-mexico/.

[66] R. Andrews, Super-Salty Murderous "Deadpool" Lurks At The Bottom Of The Gulf Of Mexico, 2016, IFLSCIENCE www.iflscience.com/environment/super-salty-murderous-de adpool-lurks-bottom-gulf-mexico/.

[67] www.thoughtco.com/geography-of-the-gulf-of-mexico-143 5544 .

[68] A. Pillsbury, The Salinity of Rivers, Scientific American. Vol. 245, No. 1, 54-65, 1981. www.sci.sdsu.edu/salton/The SalinityofRivers.html.

[69] R. Siedland, Hydraulic Investigations of the Salar de Uyuni, Bolivia, PhD Thesis, Freiberg Online Geoscience Vol. 37, 2014. ISSN: 1434-7512.

[70] A. García-Casco, J. A. Proenza, and M. A. Iturralde-Vinent, Subduction Zones of the Caribbean: the sedimentary, magmatic, metamorphic and ore-deposit records. Geologica Acta, Vol. 9, No. 3-4, 217-224, 2011. DOI: $10.1344 / 105.000001745$.

[71] B. A. S. Davisa, S. Brewerb, A. C. Stevenson and J. Guiot, The temperature of Europe during the Holocene reconstructed from pollen data Quaternary Science Reviews Vol. 22, 1701-1716, 2003 DOI:10.1016/S0277-3791(03)00173-2.

[72] W. Dansgaard, H. B. Clausen, N. Gundestrup, C. U. Hammer, S. J. Johnsen, P. M. Kristinsdottir and N. Reeh, A new Greenland deep ice core, Science, Vol. 218, 1273-1277, 1982. DOI: 10.1126/science.218.4579.1273.

[73] C. Barras, Is an Aboriginal tale of an ancient volcano the oldest story ever told? Science News, 2-11-2020, www.sciencemag.org/news/2020/02/aboriginal-tale-ancientvolcano-oldest-story-ever-told.

[74] P. M. Harris, J. Ellis, and S. Purkis, Great Bahama Bank Part I: Evaluating Water-Depth Variation on a "Flat-Topped" Isolated Carbonate Platform, Search and Discovery Article \#50960. Annual Convention and Exhibition, Houston, Texas, April 6-9, 2014, AAPG. www.searchanddiscovery.com/pdf z/documents/2014/50960harris/ndx_harris.pdf.html.

[75] hearthobservatory.nasa.gov/images/89060/little-bahama-ban $\mathrm{k}$.

[76] J. Imbrie and K. P. Imbrie, Ice ages: solving the mystery. Short Hills NJ, Enslow Publishers, 1979. ISBN: 
978-0-89490-015-0.

[77] en.wikipedia.org/wiki/Interglacial.

[78] W. Schwarzacher, Cyclostratigraphy and the Milankovitch Theory, Developments in Sedimentology 52, 1993, Elsevier, Amsterdam. ISBN: 0-444-89623-6.

[79] J. Hoefs, Stable Isotope Geochemistry, Springer-Verlag, Berlin, 2009. ISBN: 978-3-540-70703-5.
[80] en.wikipedia.org/wiki/Vienna_Standard_Mean_Ocean_Wat er.

[81] en.wikipedia.org/wiki/\%CE\%9418O.

[82] D. E. Granger, A Review of Burial Dating Methods Using $26 \mathrm{Al}$ and 10Be, Geological Society of America, Vol. 415, 2006. DOI: $10.1130 / 2006.2415(01)$.

[83] www.unis.no/the-antique-mountain-peaks-of-svalbard/. 